\title{
Associated Factors Of Metabolic Syndrome And The Role Of Oral Health Among 50 And Older Adults: from the 6th KNHANES
}

\author{
Moon-Hee Kwon \\ Dept. of Nursing, Kyungdong University, Wonju-city Gangwon-do, 26495, KOREA
}

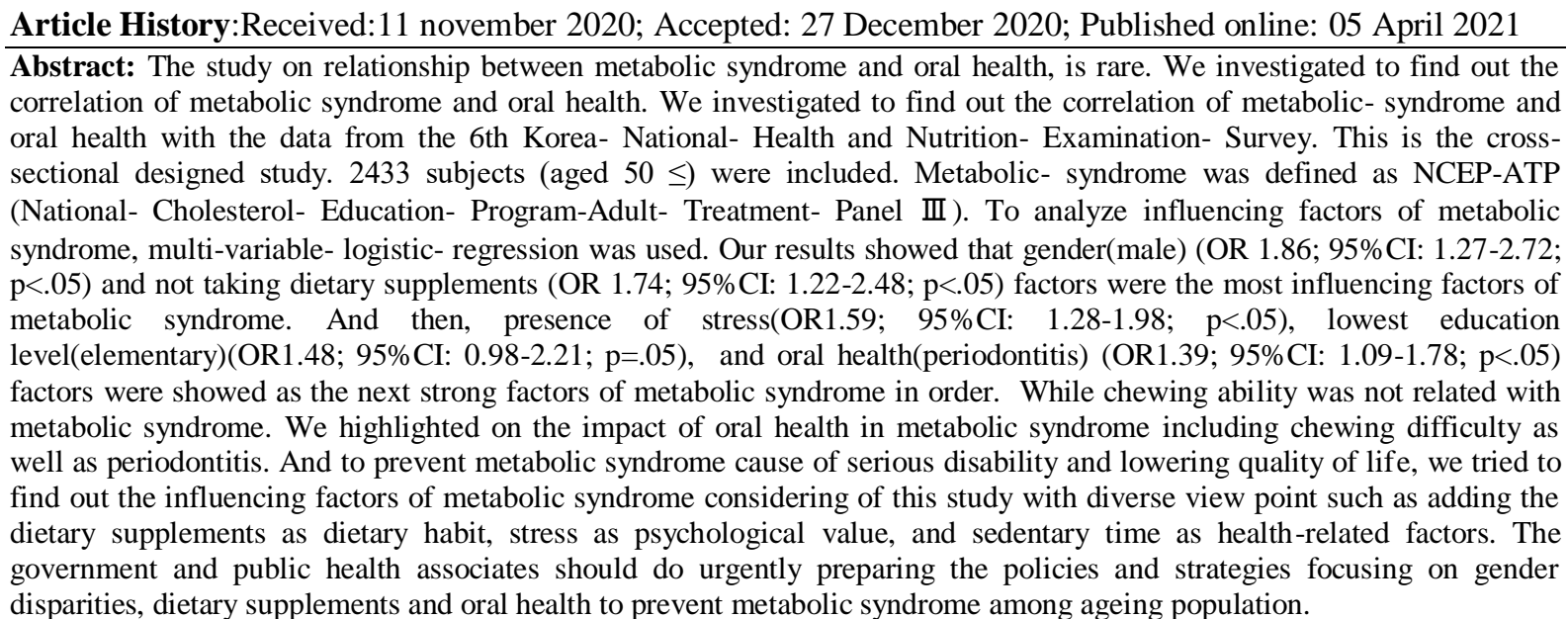

Keywords: Dietary supplements, Education level, Gender, Metabolic syndrome, Periodontitis, Stress.

\section{Introduction}

Metabolic syndrome was prevalent and increasing worldwide. Metabolic syndrome, the serious health problem resulted in cardiovascular disease, consists of hypertension, glucose intolerance, abdominal obesity, hypertriglyceridemia and low HDL cholesterol. Recently oral health factors, the major indicator of quality of life (Cervino, G., et al, 2019), were reported to being associated with metabolic- syndrome (Kim, J. S., et al, 2019; Kaur, K. K. et al, 2019). And gender disparities were also reported to be related with metabolic syndrome (Kim, J. S., et al, 2019) as well as the relationship between metabolic syndrome and healthy life style factors (Hoyas, I., \&Leon-Sanz, M. 2019; Lin, W. T., et al, 2019). And coping style and occupational stress were reported to be associated with periodontitis among workers by the cross-sectional study(Islam, M. M., et al, 2019). Also, circulation microparticles in metabolic syndrome with cardiovascular risks were reported to be associated with oxidative stress (Zahran, A. M., et al, 2019). And posttraumatic stress was reported to be related with metabolic syndrome especially in women(LIhua, M., et al, 2020).In current evidence on natural agents, they were reported to be on thoughtful perspective in oral health including periodontitis (Jaramillo Flores, M. E. ,2019). It was reported on the links that serum vitamin C and antioxidant levels were related with periodontitis (Isola, G., et al, 2019; Van der Veldena, U., 2020). Especially, the relationship between vitamin D level and metabolic syndrome was suggested as important one in obese patient as well as general people for reducing metabolic disease and increasing longevity (Moukayed, M., \& Grant, W. B.,2019). And dietary nitrate was also reported to be associated with activating of metabolic pathways and reducing of oxidative stress (Lundberg, J. O.,2018). Dietary supplements such as botanical oil and fish oil was reported to be related with metabolic syndrome as well as type-2 diabetes ( Lee, T. C. et al, 2014). In addition to that, dietary supplementation of watermelon juice was reported to being ameliorating the metabolic syndromes in obese animals (Wu, G., Collins, et al, 2007) though it has kinds of some limitation in animal subjects. And more, oral health was reported to be closely connected with improving of overall health especially among adults (Onubogu, U., et al, 2019; Ismail, F., et al, 2019; Rawal, I., et al, 2019). In addition to that, number of teeth, as the important indicator of oral health, was reported to increase the risk of metabolic syndrome among elderly (PEDRO, R. E. L., et al, 2019). Additionally, diabetes and smoking were closely associated with poor oral health such as tooth loss by recent cohort study( Kim, Y. T., et al, 2019). Through reviewing of current studies, we investigated to find out the major influencing factors of metabolic syndrome and impacting factors of oral-health of 50 and older aged Koreans using nationally representative data of 6th KNHANES. Considering potential impact on subjects and lifestyle, we included demographic, socioeconomic, health related and oral health factors.

\section{Materials and Methods}

*Corresponding author: Moon-Hee Kwon

Dept. of Nursing, Kyungdong University, Wonju-city Gangwon-do, 26495, KOREA 
Using derived from nationally representative data from 6th Knhanes (Korea- National- Health and NutritionExamination- Survey), of stratified sampling one, after exclusion of missing and not available one, this study was analyzed. The standards of NCEP-ATPIII (National- Cholesterol- Education- Program -Adult- TreatmentPanel) for the criteria of metabolic-syndrome was used for the study. This study is a cross-sectional- designed one.

\section{Study-subjects}

This study was conducted to find-out on relationship between oral health and metabolic- syndrome of 2433 consented participants, 50 aged and older, using complex-sampling-methods by multiple-logistic-regressions with SPSS (ver. 21.0).

\section{Study-analysis}

This study was analyzed by complex sampling methods. For the general characteristic of the 2433 subjects of aged 50 and over, demographic statistics methods were used. And chi-square test was used for analyzing prevalence of association between metabolic- syndrome and determinant factors. To investigate influencing factors of metabolic- syndrome and impact of oral health, multi-variable logistic regression methods with SPSS (ver. 21.0) were used. The significance- level was ( $\mathrm{p}<.05)$.

\section{Results and Discussion}

Out of 2433 participants, $42.0 \%$ were men [Table 1]. 50-64 aged group was $52.2 \%$. The prevalence of metabolic syndrome was $13.6 \%$. About $30.2 \%$ participants reported no-taking of dietary supplements. $73.2 \%$ participants had stress. The lowest educational group(elementary) was $42.9 \%$. Around $38.1 \%$ participants had periodontitis.

Table 1. General characteristics of 50 and older participants

\begin{tabular}{|c|c|c|}
\hline Variables & $\mathrm{N}(2433)$ & $\%$ \\
\hline \multicolumn{3}{|l|}{ Gender } \\
\hline Male & 1023 & 42.0 \\
\hline Female & 1410 & 58.0 \\
\hline \multicolumn{3}{|l|}{ Age } \\
\hline $50-64$ & 1271 & 52.2 \\
\hline 65 over & 1162 & 47.8 \\
\hline \multicolumn{3}{|l|}{ Residence } \\
\hline Urban (Dong) & 1851 & 76.1 \\
\hline Rural (Eup, Myeon) & 582 & 23.9 \\
\hline \multicolumn{3}{|l|}{ Marital status(spouse) } \\
\hline No & 27 & 1.1 \\
\hline Yes & 2406 & 98.9 \\
\hline \multicolumn{3}{|l|}{ Income level } \\
\hline Lowest & 562 & 23.1 \\
\hline Middle-low & 625 & 25.7 \\
\hline Middle-high & 615 & 25.3 \\
\hline Highest & 631 & 25.9 \\
\hline \multicolumn{3}{|l|}{ Education level } \\
\hline Elementary & 1044 & 42.9 \\
\hline Middle-school & 428 & 17.6 \\
\hline High-school & 593 & 24.4 \\
\hline College & 368 & 15.1 \\
\hline \multicolumn{3}{|l|}{ Smoking } \\
\hline No & 1506 & 61.9 \\
\hline Yes & 927 & 38.1 \\
\hline \multicolumn{3}{|l|}{ Drinking } \\
\hline No & 480 & 19.7 \\
\hline Yes & 1953 & 80.3 \\
\hline
\end{tabular}




\begin{tabular}{|c|c|c|}
\hline \multicolumn{3}{|l|}{ Physical activity(exercise) } \\
\hline No & 1860 & 76.4 \\
\hline Yes & 573 & 23.6 \\
\hline \multicolumn{3}{|l|}{ Stress recognition } \\
\hline No & 653 & 26.8 \\
\hline Yes & 1780 & 73.2 \\
\hline \multicolumn{3}{|l|}{ Taking dietary supplements } \\
\hline No & 735 & 30.2 \\
\hline Yes & 1698 & 69.8 \\
\hline \multicolumn{3}{|l|}{ Sedentary time } \\
\hline Less than $5 \mathrm{hrs}$. & 662 & 27.2 \\
\hline Over 5 hrs. & 1771 & 72.8 \\
\hline \multicolumn{3}{|l|}{ Chewing difficulty } \\
\hline Severe & 919 & 37.8 \\
\hline Moderate & 405 & 16.6 \\
\hline None & 1109 & 45.6 \\
\hline \multicolumn{3}{|l|}{ Periodontitis } \\
\hline No & 1506 & 61.9 \\
\hline Yes & 927 & 38.1 \\
\hline \multicolumn{3}{|l|}{ Metabolic syndrome } \\
\hline No & 2101 & 86.4 \\
\hline Yes & 332 & 13.6 \\
\hline
\end{tabular}

Table 2. show prevalence of association between metabolic- syndrome and determinant- factors with impact of oral health among Korean 50 and older adults. The prevalence of metabolic- syndrome was $55.7 \%$ (men) and $44.3 \%$ (women). And prevalence of metabolic syndrome was showed as smoking (50.3\%), yes feeling stress (64.5\%), not taking dietary supplements (35.5\%), and periodontitis (45.5\%).

Table 2. Prevalence of Association between metabolic syndrome and determinant factors

\begin{tabular}{|c|c|c|c|}
\hline & \multicolumn{2}{|c|}{ Metabolic syndrome } & \multirow[t]{2}{*}{$\mathrm{P}$-value } \\
\hline & Yes & No & \\
\hline & $\mathrm{N}(\%)$ & $\mathrm{N}(\%)$ & \\
\hline \multicolumn{4}{|l|}{ Variables } \\
\hline Gender & & & \multirow[t]{3}{*}{$<.001$} \\
\hline Male & $185(55.7)$ & $838(39.9)$ & \\
\hline Female & $147(44.3)$ & $1263(60.1)$ & \\
\hline \multicolumn{3}{|l|}{ Age } & \multirow[t]{3}{*}{.137} \\
\hline $50-64$ & $186(56.0)$ & $1085(51.6)$ & \\
\hline 65 over & $146(44.0)$ & $1061(48.4)$ & \\
\hline \multicolumn{4}{|l|}{ Residence } \\
\hline Urban(Dong) & $2509(78.0)$ & $1592(75.8)$ & \multirow[t]{2}{*}{.374} \\
\hline Rural(Eup, Myeon) & $73(22.0)$ & $50.9(24.2)$ & \\
\hline \multicolumn{3}{|l|}{ Marital status(spouse) } & \multirow[t]{3}{*}{.458} \\
\hline No & $5(1.5)$ & $22(1.0)$ & \\
\hline Yes & $327(985)$ & 2079(99.0) & \\
\hline \multicolumn{3}{|l|}{ Income level } & \multirow[t]{3}{*}{.895} \\
\hline Lowest & $78(23.5)$ & $484(23.0)$ & \\
\hline Middle-low & $85(25.6)$ & $540(25.7)$ & \\
\hline
\end{tabular}


Associated factors of Metabolic Syndrome and the role of Oral health among 50 and older adults: from the 6th KNHANES

\begin{tabular}{|c|c|c|c|}
\hline Middle-high & $88(26.5)$ & $527(25.1)$ & \\
\hline Highest & $81(24.4)$ & $550(26.2)$ & \\
\hline \multicolumn{3}{|l|}{ Education level } & \multirow[t]{5}{*}{.897} \\
\hline Elementary & $142(42.8)$ & $902(42.9)$ & \\
\hline Middle & $56(16.9)$ & $372(17.7)$ & \\
\hline High & $86(25.9)$ & $507(24.1)$ & \\
\hline College & $48(14.5)$ & $320(15.2)$ & \\
\hline \multicolumn{3}{|l|}{ Smoking } & \multirow[t]{3}{*}{$<.001$} \\
\hline No & $165(49.7)$ & $1341(63.8)$ & \\
\hline Yes & $167(50.3)$ & $760(36.2)$ & \\
\hline \multicolumn{3}{|l|}{ Drinking } & \multirow[t]{3}{*}{.064} \\
\hline No & $53(16.0)$ & $427(20.3)$ & \\
\hline Yes & $279(84.0)$ & 1674(79.7) & \\
\hline \multicolumn{3}{|l|}{ Physical activity(exercise) } & \multirow[t]{3}{*}{.560} \\
\hline No & $258(77.7)$ & $1602(76.2)$ & \\
\hline Yes & $74(22.3)$ & $499(23.8)$ & \\
\hline Stress Recognition & & & $<.001$ \\
\hline No & $118(35.5)$ & $535(25.5)$ & \\
\hline Yes & $214(64.5)$ & $1566(74.5)$ & \\
\hline Taking dietary supplements & & & .023 \\
\hline No & $118(35.5)$ & $617(29.4)$ & \\
\hline Yes & $214(64.5)$ & $1484(70.6)$ & \\
\hline Sedentary time & & & .507 \\
\hline Less than $5 \mathrm{hrs}$. & $85(25.6)$ & $577(27.5)$ & \\
\hline Over hrs. & $247(74.4)$ & $1524(72.5)$ & \\
\hline \multicolumn{4}{|l|}{ Oral Health } \\
\hline \multicolumn{3}{|l|}{ Chewing difficulty } & \multirow[t]{4}{*}{.947} \\
\hline Severe & $128(38.6)$ & $791(37.7)$ & \\
\hline Moderate & $54(16.3)$ & $351(16.7)$ & \\
\hline None & $150(45.1)$ & $959(45.6)$ & \\
\hline \multicolumn{3}{|l|}{ Periodontitis } & \multirow[t]{3}{*}{.003} \\
\hline No & $181(54.5)$ & $1325(63.1)$ & \\
\hline Yes & $151(45.5)$ & $776(36.9)$ & \\
\hline
\end{tabular}

Table 3. depicts the major determinants of metabolic syndrome and the impact of oral among Korean 50 and over aged adults. By multi-variable-logistic-regression explained that gender(male) (OR1.86;95\%CI:1.27-2.72; $\mathrm{p}<.05$ ), not taking dietary supplements (OR1.74;95\%CI:1.22-2.48; p<.05) factors were the strongest one of metabolic syndrome. And the next determinant factors were presence of stress(OR1.59;95\%CI:1.28-1.98; $\mathrm{p}<.05)$, lowest education level(OR1.48;95\%CI:0.98-2.21; p<.05), oral health factor(periodontitis) (OR1.39; 95\%CI: 1.09-1.78; $\mathrm{p}<.05)$, were the major determinants of metabolic syndrome respectively. While the related smoking and drinking factors were showed as not associated one with no significance.

Table3. The determinant factors of metabolic syndrome and the impact of oral health of 50 and older Koreans by multi-variable logistic regression

\begin{tabular}{|c|c|c|c|c|}
\hline \multirow{2}{*}{$\begin{array}{l}\text { variables } \\
\text { Gender }\end{array}$} & OR & \multicolumn{2}{|c|}{$95 \% \mathrm{CI}$} & p-value \\
\hline & & & & \\
\hline Male & 1.86 & 1.27 & 2.72 & .001 \\
\hline Female & & Reference & & \\
\hline Age & & & & \\
\hline
\end{tabular}




\begin{tabular}{|c|c|c|c|c|}
\hline $50-64$ & 1.28 & .98 & 1.65 & .061 \\
\hline 65 over & & Reference & & \\
\hline \multicolumn{5}{|l|}{ Socio-economic status } \\
\hline \multicolumn{5}{|l|}{ Residence } \\
\hline Urban(Dong) & & Reference & & \\
\hline Rural(Eup, Myeon) & 0.84 & .63 & 1.13 & .262 \\
\hline \multicolumn{5}{|l|}{ Marital status(spouse) } \\
\hline $\begin{array}{l}\text { No } \\
\text { Yes }\end{array}$ & 1.19 & $\begin{array}{c}.43 \\
\text { Reference }\end{array}$ & 3.24 & .730 \\
\hline \multicolumn{5}{|l|}{ Income level } \\
\hline Lowest & 1.11 & .80 & 1.55 & .522 \\
\hline Middle-low & 1.01 & .70 & 1.44 & .961 \\
\hline $\begin{array}{r}\text { Middle-high } \\
\text { Highest }\end{array}$ & 1.01 & $\begin{array}{c}.71 \\
\text { Reference }\end{array}$ & 1.42 & .968 \\
\hline \multicolumn{5}{|l|}{ Education level } \\
\hline Elementary & 1.48 & .98 & 2.21 & .050 \\
\hline Middle & 1.16 & .74 & 1.78 & .519 \\
\hline High & 1.26 & .85 & 1.86 & .249 \\
\hline College & & Reference & & \\
\hline \multicolumn{5}{|l|}{ Health-related status } \\
\hline \multicolumn{5}{|l|}{ Smoking } \\
\hline No & & Reference & & \\
\hline Yes & 1.15 & .79 & 1.67 & .465 \\
\hline \multicolumn{5}{|l|}{ Drinking } \\
\hline Yes & 1.03 & 0.74 & 1.45 & .825 \\
\hline \multicolumn{5}{|l|}{$\begin{array}{l}\text { Physical } \\
\text { activity(exercise) }\end{array}$} \\
\hline No & 1.20 & .89 & 1.61 & .215 \\
\hline Yes & & Reference & & \\
\hline \multicolumn{5}{|l|}{ Psychological status } \\
\hline \multicolumn{5}{|l|}{ Stress recognition } \\
\hline No & & Reference & & \\
\hline Yes & 1.59 & 1.28 & 1.98 & .001 \\
\hline \multicolumn{5}{|l|}{$\begin{array}{l}\text { Taking dietary } \\
\text { supplements }\end{array}$} \\
\hline No & 1.74 & 1.22 & 2.48 & .001 \\
\hline Yes & & Reference & & \\
\hline \multicolumn{5}{|l|}{ Sedentary time } \\
\hline Less than $5 \mathrm{hrs}$. & & Reference & & \\
\hline Over 5hrs. & 1.13 & 0.86 & 1.48 & .360 \\
\hline \multicolumn{5}{|l|}{$\begin{array}{c}\text { Oral Health } \\
\text { Chewing difficulty }\end{array}$} \\
\hline Severe & .924 & .657 & 1.301 & .651 \\
\hline Moderate & .910 & .692 & 1.196 & .498 \\
\hline None & & Reference & & \\
\hline Periodontitis & & & & \\
\hline
\end{tabular}



6th KNHANES

\begin{tabular}{|r|c|c|c|c|}
\hline No & & Reference & & \\
\hline Yes & 1.39 & 1.09 & 1.78 & .007 \\
\hline
\end{tabular}

These findings suggest that men compared to women, not taking of dietary supplements, much stress, lower education level and periodontitis, as the indicator of oral health, were the major determinants of metabolic syndrome with analyzing 2433 participants aged 50 and older participants of the 6th Korea- National- Health and Nutrition- Examination- Survey. The prevalence of metabolic- syndrome was 13.6\%. And this prevalence of metabolic syndrome result was low compared to that of another study (Kim, Y. H., et al, 2018) and these results were thought to be due to the total prevalence regardless of gender. Regarding gender (male), which was found to be the strongest factor of metabolic syndrome in this study, was mainly having common with the results of other studies (Kim, Y. H., et al, 2018; Jang, I., \& Kim, J. S., 2019) even though they had some difference in age of participants. But it was not consistent with the results of another studies in case of posttraumatic stress of women who had more metabolic risk (LIhua, M., et al, 2020) and having more metabolic risks in female nurses by an observational study(Chico-Barba, G., et al, 2019). With key regard to dietary supplements, as identified as one of the strongest factor of metabolic syndrome through this study, they have been identified to influence on the metabolic syndrome in several studies (Isola, G., et al, 2019; Moukayed, M., \& Grant, W. B., 2019; Lee, T. C., et al, 2014; Wu, G., et al, 2007 ). In addition to that, the cardio-metabolic effect of dietary nitrate was reported to be very critical in the point of view of including mitochondrial respiration in health and disease as well as metabolic effects (Lundberg, J. O., et al, 2018). And the results of this present study on the association between natural agents and oral health like periodontal health were supported by current studies (Jaramillo Flores, M. E., 2019; Isola, G., et al, 2019). Concerning stress, which was identified as the determinant factor of this study, that result was supported in some aspects by another studies(Zahran, A. M., et al, 2019; LIhua, M., et al, 2020). Especially, high stress was also known as being associated with taking the risk of periodontitis (Islam, M. M., et al, 2019). 50-64 aged group compared to 65 and older group was more in being risk of metabolic- syndrome of this study and this result was supported by another study (PEDRO, R. E. L., et al, 2019). In the point of view of periodontitis, as a key indicator of oral health, which was identified as the strong influencing factor of metabolic syndrome of this study, was partially in consistent with the result of another study even though there are difference in the aspects of racial sample and study design (Onubogu, U., et al, 2019) and it was supported by another study which was reported on association between oral health and metabolic- syndrome among elderly (PEDRO, R. E. L., et al, 2019) even though the difference in gender. And that, even the awareness and habits of oral care was reported to be contributed to improving of life satisfaction as well as lifestyles of the elderly (Hirano, M., et al, 2019). And poor oral health like periodontitis was shown to be seriously related with diabetes, one of the metabolic components (Rawal, I., et al, 2019) including peripheral vascular disease (Wang, J., et al, 2019) and these results were partially consistent with our results. Moreover, periodontitis was reported to be associated with occupational stress and low coping condition (Islam, M. M., et al, 2019). Chewing, which was related with tooth loss causing of worsening cognition (Zahran, A. M., et al, 2019; Lee, K. H., \& Choi, Y. Y., 2019) was already identified as the indicator of good oral health (Kim, Y. T., et al, 2019; Natarajan, P., et al, 2019) even though it was not significant in this study. In view of education level, as the indicator of socio-economic status, it was suggested the major factor of metabolic syndrome through this study, that was supported by another study which was reported on the close relationship between education level, alcohol consumption and physical activity and metabolic syndrome (Kim, Y. H., Kim, H., \& Jee, H., 2018). Smoking and alcohol consumption which were known as the important factors of metabolic syndrome even though they were not significant in this study, were not consistent with the results of other study (Kim, Y. H., Kim, H., \& Jee, H., 2018) despite of common results in the aspects of education level and they seem to be cause of gender difference by study design. The strength of this study was based on the nationally representative data with stratified survey in the point of reliability and validity. Major consideration of this study was including and dealing with the importance of the oral health variables such as chewing level and periodontitis as the critical role of potential and influencing on general health of middle- older- adults. The limitation of this study is in cross-sectional nature design. To conclude, gender(male), not taking of dietary supplements, stress as the psychological factor, lower education level and periodontitis as the indicator of oral health were the influencing major determinants of metabolic syndrome. So, public health professionals might be needed to manage the education strategies considering age, gender disparities, education level and promoting oral health to prevent metabolic syndrome. Further researches might be necessary to explore the mechanisms for validity between metabolic syndrome and oral health by gender to prepare early public and nursing interventions in this population.

\section{Conclusion}

In conclusion, it was suggested that gender(male) and not taking of dietary supplements were the major determinants of metabolic syndrome. And then, the next determinant factors were stress of the psychological 
status, elementary school in lowest education level and periodontitis in oral health were the important determinants of metabolic syndrome respectively. Therefore, public health and nursing professionals might urgently consider managing the public education strategies heightening on age, gender disparities, dietary habits and improving oral health as well as including to prevent metabolic syndrome. Continued researches should be accomplished to find out the links and associations of metabolic syndrome and dietary habits, psychological areas as well as oral health by gender for the future successful ageing.

\section{Funding Support - No funding Support}

\section{Conflict of Interest - The authors declare that they have no conflict of interest}

\section{References (Harvard Style)}

1. Cervino, G., Terranova, A., Briguglio, F., De Stefano, R., Famà, F., D’Amico, C., ... \&Scoglio, C., 2019. Diabetes: Oral health related quality of life and oral alterations. BioMed research international, 2019. | https://doi.org/10.1155/2019/5907195

2. Kim, J. S., Kim, S. Y., Byon, M. J., Lee, J. H., Jeong, S. H., \& Kim, J. B., 2019. Association between p eriodontitis and metabolic syndrome in a Korean nationally representative sample of adults aged 35-79 years. International journal of environmental research and public health, 16(16), 2930.

3. Kaur, K. K., 2019. With the Advancement of Knowledge Regarding Correlation of Oral Health and Ob esity Role of Dentist Emphasized to Act in Prevention of Further Progression, along with Association with Pregnancy, Fetal Macrosomia, Beta 3 Adren-ergic Receptor Polymorphisms, Energy Drinks. EC Dental Science, 18, pp.1927-1938.

4. Hoyas, I., \&Leon-Sanz, M., 2019. Nutritional challenges in metabolic syndrome. Journal of clinical me dicine, 8(9), pp.1301.

5. Lin, W. T., Lee, C. Y., Tsai, S., Huang, H. L., Wu, P. W., Chin, Y. T., ... \&Lee, C. H., 2019. Clustering of metabolic risk components and associated lifestyle factors: A nationwide adolescent study in Taiwa n. Nutrients, 11(3), pp.584.

6. Islam, M. M., Ekuni, D., Yoneda, T., Yokoi, A., \& Morita, M., 2019. Influence of Occupational Stress and Coping Style on Periodontitis among Japanese Workers: A Cross-Sectional Study. International jo urnal of environmental research and public health, 16(19), pp.3540.

7. Zahran, A. M., Sayed, S. K., Abd El Hafeez, H. A., Khalifa, W. A., Mohamed, N. A., \& Hetta, H. F., 2 019. Circulating microparticle subpopulation in metabolic syndrome: relation to oxidative stress and co agulation markers. Diabetes, metabolic syndrome and obesity: targets and therapy, 12, pp.485.

8. LIhua, M., Tao, Z., Hongbin, M., Hui, W., Caihong, J., \& Xiaolian, J., 2020. Metabolic syndrome risk i $\mathrm{n}$ relation to posttraumatic stress disorder among trauma-exposed civilians in Gansu Province, China. Medicine, 99(1).

9. Jaramillo Flores, M. E. 2019., Cocoa flavanols: Natural agents with attenuating effects on metabolic sy ndrome risk factors. Nutrients, 11(4), pp.751.

10. Isola, G., Polizzi, A., Muraglie, S., Leonardi, R., \& Lo Giudice, A., 2019. Assessment of vitamin C and antioxidant profiles in saliva and serum in patients with periodontitis and ischemic heart disease. Nutri ents, 11(12), pp.2956.

11. Van der Veldena, U., 2020. Vitamin C and Its Role in Periodontal Diseases-The Past and the Present: A Narrative Review. Oral Health Prev Dent, 18, pp.115-124.

12. Moukayed, M., \& Grant, W. B., 2019. Linking the metabolic syndrome and obesity with vitamin D stat us: risks and opportunities for improving cardiometabolic health and well-being. Diabetes, Metabolic S yndrome and Obesity: Targets and Therapy, 12, pp.1437.

13. Lundberg, J. O., Carlström, M., \& Weitzberg, E., 2018. Metabolic effects of dietary nitrate in health an d disease. Cell metabolism, 28(1), pp.9-22.

14. Lee, T. C., Ivester, P., Hester, A. G., Sergeant, S., Case, L. D., Morgan, T., ... \& Chilton, F. H., 2014. T he impact of polyunsaturated fatty acid-based dietary supplements on disease biomarkers in a metaboli c syndrome/diabetes population. Lipids in health and disease, 13(1), pp.196.

15. Wu, G., Collins, J. K., Perkins-Veazie, P., Siddiq, M., Dolan, K. D., Kelly, K. A., ... \& Meininger, C. J. , 2007. Dietary supplementation with watermelon pomace juice enhances arginine availability and amel iorates the metabolic syndrome in Zucker diabetic fatty rats. The Journal of nutrition, 137(12), pp.2680 -2685 .

16. Onubogu, U., Mansfield, W. M., \& Ozbek, I. N., 2019. Oral Healthcare Measures to Improve Overall Health in Older Adults. J Comp Nurs Res Care, 4, pp.156.

17. Ismail, F., Muneer, M. U., Ahmed, A. R., Hussain, M. W., Farhan, M., Khan, M. U. Q., \& Kashif, M., 2019. FACTORS AFFECTING COGNITION IN INDIVIDUALS WITH TOOTH LOSS. Annals of De ntal Specialty, Vol, 7(4), pp.7.

18. Rawal, I., Ghosh, S., Hameed, S. S., Shivashankar, R., Ajay, V. S., Patel, S. A., ... \& Prabhakaran, D., 
2019. Association between poor oral health and diabetes among Indian adult population: potential for $\mathrm{i}$ ntegration with NCDs. BMC oral health, 19(1), pp.191.

19. PEDRO, R. E. L., BUGONE, É., DOGENSKI, L. C., CARDOSO, M. Z., HÜBNER DA SILVA, A., LI NDEN, M. S. S., ... \& VALDEZ, E. J., 2019. Relationship between dentition, anthropometric measure ments, and metabolic syndrome in the elderly. Revista de Odontologia da UNESP, pp.48.

20. Kim, Y. T., Choi, J. K., Kim, D. H., Jeong, S. N., \& Lee, J. H., 2019. Association between health status and tooth loss in Korean adults: longitudinal results from the National Health Insurance Service-Health Examinee Cohort, 2002-2015. Journal of Periodontal \& Implant Science, 49(3), pp.158-170.

21. Kim, Y. H., Kim, H., \& Jee, H., 2018. Effects of socioeconomic status, health behavior, and physical ac tivity on the prevalence of metabolic syndrome. Journal of exercise rehabilitation, 14(2), pp.183.

22. Jang, I., \& Kim, J. S., 2019. Risk of Cardiovascular Disease Related to Metabolic Syndrome in College Students: A Cross-Sectional Secondary Data Analysis. International journal of environmental researc $h$ and public health, 16(19), pp.3708.

23. Chico-Barba, G., Jiménez-Limas, K., Sánchez-Jiménez, B., Sámano, R., Rodríguez-Ventura, A. L., Cas tillo-Pérez, R., \& Tolentino, M., 2019. Burnout and metabolic syndrome in female nurses: an observati onal study. International journal of environmental research and public health, 16(11), pp.1993.

24. Hirano, M., Imai, H., Oya, M., Hirano, M., Imai, H., \& Oya, M., 2019. Effect of Awareness and Habits of Oral Care on Life Satisfaction. Oral health \& preventive dentistry, 17(2), pp.131-138.

25. Wang, J., Geng, X., Sun, J., Zhang, S., Yu, W., Zhang, X., \& Liu, H., 2019. The risk of periodontitis fo $\mathrm{r}$ peripheral vascular disease: a systematic review. Reviews in cardiovascular medicine, 20(2), pp.81-89

26. Lee, K. H., \& Choi, Y. Y., 2019. Association between oral health and dementia in the elderly: a populat ion-based study in Korea. Scientific reports, 9(1), pp.1-8.

27. Natarajan, P., Choudhury, M., Seenivasan, M. K., Jeyapalan, K., Natarajan, S., \& Vaidhyanathan, A. K ., 2019. Body Mass Index and Tooth Loss: An Epidemiological Study in a Sample of Suburban South I ndian Population. Journal of Pharmacy \& Bioallied Sciences, 11(Suppl 2), S402. 